\title{
Overloading Human Aortic Smooth Muscle Cells with Low Density Lipoprotein-Cholesteryl Esters Reproduces Features of Atherosclerosis in Vitro
}

\author{
Joseph L. Goldstein, Richard G. W. Anderson, L. Maximillian Buja, \\ SANDIP K. BASU, and MICHAEL S. BROWN \\ From the Departments of Internal Medicine, Cell Biology, and Pathology, University of Texas \\ Health Science Center at Dallas, Dallas, Texas 75235
}

\begin{abstract}
A B S T R A C T Human aortic smooth muscle cells accumulate only small amounts of cholesteryl esters in tissue culture, even when incubated for prolonged periods with high levels of plasma low density lipoprotein (LDL). This failure to overaccumulate LDL-cholesteryl esters is due to an LDL-mediated feedback suppression of the activity of the cell surface LDL receptor, a regulatory action that limits the rate at which the cells take up LDL. This regulatory system can be bypassed by incubating smooth muscle cells with LDL that has been given a strong positive charge by covalent linkage with $\mathrm{N}, \mathrm{N}$-dimethyl-1,3propanediamine (DMPA-LDL). The unregulated uptake of DMPA-LDL produces a massive deposition of cholesteryl esters in the form of inclusions within the cell. These inclusions take up lipid stains and exhibit positive birefringence with formée crosses that are typical of liquid crystals of cholesteryl esters. By electron microscopy, the cholesteryl ester inclusions appear as homogeneous gray cytoplasmic lipid droplets. The current studies demonstrate that the unregulated uptake of LDL-cholesteryl esters by human
\end{abstract}

Dr. Goldstein is the recipient of U. S. Public Health Service Research Career Development Award GM 70,277. Dr. Brown is an Established Investigator of the American Heart Association.

Received for publication 4 March 1977. aortic smooth muscle cells can reproduce in vitro the major biochemical and morphological alterations that occur within smooth muscle cells in vivo during the process of atherosclerosis.

\section{INTRODUCTION}

Early in human atherosclerosis large amounts of cholesteryl esters accumulate within smooth muscle cells of the arterial intima (1-3). These cholesteryl esters form globular inclusions with the following characteristics: $(a)$ they take up lipid stains such as Oil Red 0 (1-3); (b) they exhibit positive birefringence of the type shown by pure liquid crystals of cholesteryl esters (4); and (c) they appear in the electron microscope as homogeneous electron dense spheres that may or may not be surrounded by a tripartite limiting membrane $(3,5)$.

Most investigators agree that the cholesterol component of the cholesteryl esters in smooth muscle cells originates from plasma lipoproteins (6). However, attempts to reproduce the pathologic changes of atherosclerosis in vitro by incubating cultured smooth muscle cells with large amounts of plasma lipoproteins from normal or hyperlipidemic animals or man have been disappointing. The maximal level of intracellular cholesteryl esters that can be attained by this approach (7-9) is much lower than the mas- 
sive levels seen in naturally occurring or experimentally induced atherosclerosis $(2,6)$.

A possible explanation for the failure of large amounts of lipoproteins to produce a pathologic overaccumulation of cholesteryl esters in smooth muscle cells has emerged from recent studies of the regulation of lipoprotein uptake in cultured human fibroblasts (10-12). For fibroblasts to take up plasma lipoproteins in amounts sufficient to expand their intracellular cholesteryl ester pool, the cells must first bind the lipoprotein at a specific cell surface receptor site. This receptor is either absent or greatly deficient in cells from patients with homozygous familial hypercholesterolemia $(\mathrm{FH}){ }^{1}$ In normal cells this receptor binds the major cholesterol-carrying lipoprotein in human plasma, low density lipoprotein (LDL). After its binding to the receptor, LDL is internalized by adsorptive endocytosis and delivered to lysosomes where its cholesteryl esters are hydrolyzed. The resulting free cholesterol is made available for plasma membrane synthesis and for regulatory actions. Any excess cholesterol that enters the cell through the LDL pathway is reesterified through an activation of a microsomal acyl-CoA:cholesterol acyltransferase and stored within the cell as cholesteryl esters. As cholesteryl esters begin to accumulate, the synthesis of the LDL receptor becomes suppressed and hence the cells limit their uptake of LDL. This feedback suppression of the synthesis of the LDL receptor prevents fibroblasts from accumulating massive amounts of cholesteryl esters even when the cells are exposed to high concentrations of LDL.

The above control mechanism can be overcome and an unregulated uptake of LDL can be achieved in fibroblasts by incubating the cells with LDL that has been rendered polycationic by the covalent attachment of $\mathrm{N}, \mathrm{N}$-dimethyl-1,3-propanediamine (DMPA) residues to the lipoprotein (13). This positivelycharged DMPA-LDL binds to nonspecific negativelycharged sites on the cell surface from which it is taken up by the fibroblasts through a process that does not involve the physiologic LDL receptor (13). ${ }^{2}$

In the current studies, we have utilized the information learned from the metabolism of DMPA-LDL in fibroblasts to overload cultured human aortic smooth muscle cells with cholesteryl esters, thus reproducing an in vitro counterpart of the in vivo atherosclerotic lesion.

\footnotetext{
${ }^{1}$ Abbreviations used in this paper: DMPA, N,N-dimethyl1,3-propanediamine; FCS, fetal calf serum; FH, familial hypercholesterolemia; LDL, low density lipoprotein; LPDS, lipoprotein-deficient serum.

${ }^{2}$ Basu, S. K., R. G. W. Anderson, J. L. Goldstein, and M. S. Brown. 1977. Metabolism of cationized lipoproteins by human fibroblasts: Biochemical and morphologic correlations. J. Cell Biol. In press.
}

\section{METHODS}

Aortic smooth muscle cells. The normal smooth muscle cell line was derived from intimal-medial segments of the thoracic aorta of a 6-mo-old human fetus and was obtained with informed consent of the parents. The FH homozygote smooth muscle cell line was derived from an 8-yr-old girl (M. C.) whose clinical features have been described previously (14). Segments of M. C.'s thoracic aorta were removed during aortic valve replacement in October 1976. With the informed consent of M. C.'s parents, these segments were used for tissue culture. The smooth muscle cells were cultured by the method of Ross (15) and used between the 4 th and 10th passage. By phase contrast microscopy the cells were observed to grow in multiple overlapping layers, and by electron microscopy they showed myofilaments and dense bodies that are characteristic of aortic smooth muscle cells in culture (15).

Stock cultures were maintained in a humidified incubator $\left(5 \% \mathrm{CO}_{2}\right)$ at $37^{\circ} \mathrm{C}$ in $250-\mathrm{ml}$ flasks containing $10 \mathrm{ml}$ of growth medium consisting of Eagle's minimum essential medium (Grand Island Biological Co., Grand Island, N.Y., catalogue no. F-11) supplemented with penicillin (100 U/ml); streptomycin $(100 \mu \mathrm{g} / \mathrm{ml}) ; 20 \mathrm{mM}$ Tricine-chloride, $\mathrm{pH} 7.4 ; 24 \mathrm{mM}$ $\mathrm{NaHCO}_{3} ; 1 \%(\mathrm{vol} / \mathrm{vol})$ nonessential amino acids; and $10 \%$ (vol/vol) fetal calf serum (FCS). For each experiment, on day 0 confluent monolayers of cells from stock flasks were dissociated with $0.05 \%$ trypsin- $0.02 \%$ EDTA solution, and 1 $\times 10^{5}$ cells were seeded into each $60-\mathrm{mm}$ Petri dish containing $3 \mathrm{ml}$ of growth medium with $10 \%$ FCS.

Lipoproteins. Human LDL $(d=1.019-1.063 \mathrm{~g} / \mathrm{ml})$ and lipoprotein-deficient serum (LPDS) $(d>1.215 \mathrm{~g} / \mathrm{ml})$ were obtained from the plasma of healthy subjects and prepared by differential ultracentrifugation (16). Calf LPDS (16), ${ }^{125} \mathrm{I}$ labeled LDL (17), and DMPA-LDL (13) were prepared as described in the referenced articles.

Biochemical assays. Measurements of surface-bound, heparin-releasable ${ }^{125}$ I-LDL (18) and degradation of ${ }^{125}$ I-LDL (19) in smooth muscle cell monolayers were carried out as described for fibroblasts. The content of free and esterified cholesterol in smooth muscle cells was determined by gasliquid chromatography $(20)$. Protein was determined by the Lowry method (21).

Electron microscopy. Monolayers were fixed in situ for 30 min with $3 \%$ glutaraldehyde in $0.1 \mathrm{M}$ sodium phosphate, $\mathrm{pH} 7.3$, scraped from the dish, and centrifuged $\left(5 \mathrm{~min}, 4^{\circ} \mathrm{C}\right.$, $12,000 \mathrm{rpm})$. Cells were postfixed with $2 \% \mathrm{OsO}_{4}$ in $0.1 \mathrm{M}$ sodium phosphate, $\mathrm{pH} 7.3$, dehydrated, embedded in araldite, and stained with uranyl acetate and lead citrate.

Oil Red 0 staining. Monolayers were grown on glass coverslips, fixed with $6 \%$ paraformaldehyde in $0.1 \mathrm{M}$ sodium phosphate, $\mathrm{pH} 7.3$, and stained with Oil Red 0 and doublestrength Harris hematoxylin.

Polarizing light microscopy. Monolayers were grown on glass coverslips that were subsequently mounted on glass slides. To enhance birefringence, the slides were first warmed to $40-45^{\circ} \mathrm{C}$ for $10 \mathrm{~min}$, which caused the initial birefringence to disappear, after which they were cooled to $10^{\circ} \mathrm{C}$ for $10 \mathrm{~min}$, and examined immediately thereafter $(4,22)$. The cells were photographed under polarizing optics with a Zeiss Photomicroscope III (Carl Zeiss, Inc. New York).

\section{RESULTS}

The experiment in Fig. 1 compares the ability of native LDL and DMPA-LDL to produce an accumulation of cholesteryl esters in smooth muscle cells. Since 

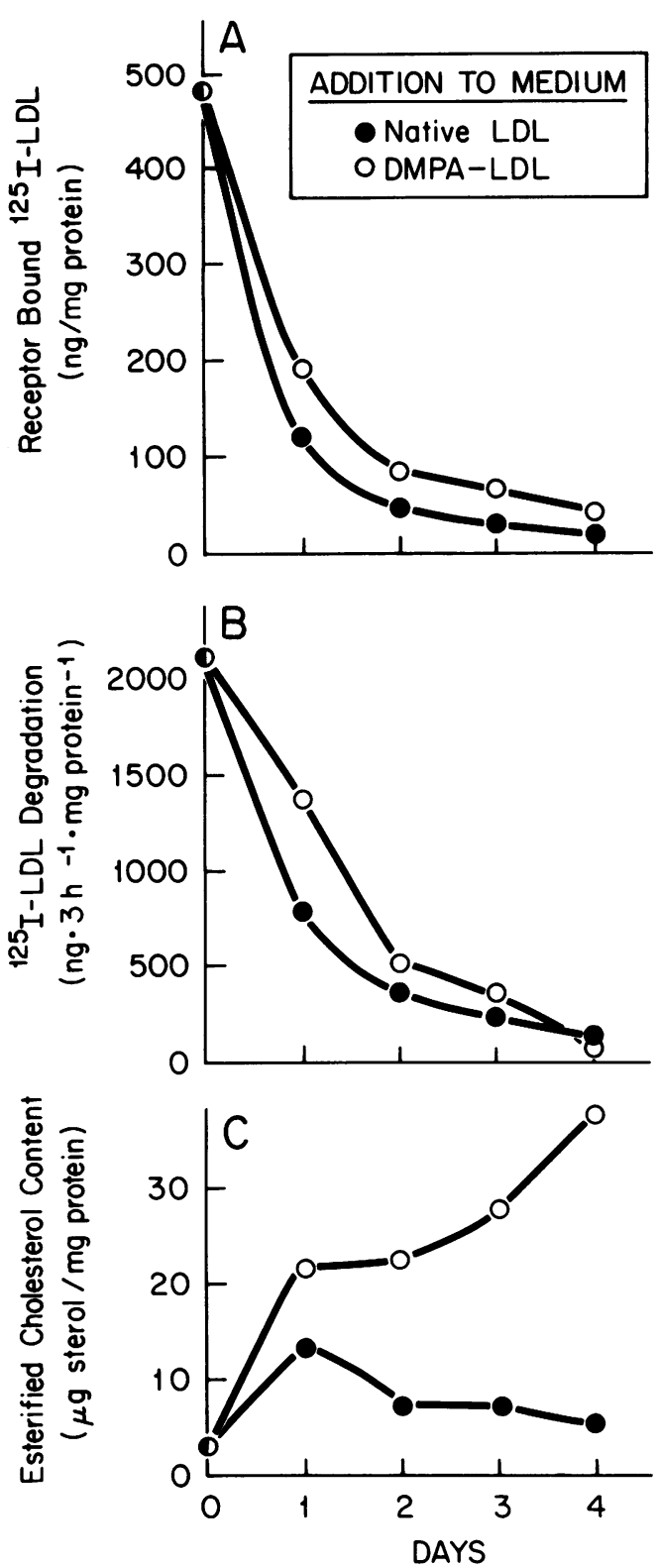

FIGURE 1 Changes in the ability of normal aortic smooth muscle cells to bind (A) and degrade (B) ${ }^{125}$ I-LDL and changes in the cellular content of cholesteryl esters (C) after incubation with native LDL (O) or DMPA-LDL (O). On day $0,1 \times 10^{5}$ cells were seeded into 60-mm Petri dishes containing $3 \mathrm{ml}$ of medium with $10 \%$ FCS. On days 4 and 7 , the cells received fresh medium containing $10 \%$ calf LPDS. On day 10 (zero time), the medium was replaced with $2 \mathrm{ml}$ of fresh medium containing 5\% calf LPDS and either $20 \mu \mathrm{g}$ protein $/ \mathrm{ml}$ of native LDL (O) or $5 \mu \mathrm{g}$ protein $/ \mathrm{ml}$ of DMPA-LDL (O). Every $24 \mathrm{~h}$ throughout the experiment, the medium was replaced with fresh medium containing the same concentration of the indicated lipoprotein. Each day a group of dishes was divided into two sets. In one set (Panels $A$ and B), each monolayer was washed twice with medium containing 5\% human LPDS, after which each dish received $2 \mathrm{ml}$ of medium containing $5 \%$ human LPDS and
TABLE I

Content of Free and Esterified Cholesterol in Normal Aortic Smooth Muscle Cells after Repeated Incubation with Native LDL or DMPA-LDL in the Presence of Two Different Concentrations of FCS

\begin{tabular}{cccccc}
\hline \multicolumn{2}{c}{ Addition to medium } & & \multicolumn{2}{c}{$\begin{array}{c}\text { Cellular cholesterol } \\
\text { content }\end{array}$} & \\
\cline { 1 - 2 } $\begin{array}{c}\text { Concentra- } \\
\text { tion of FCS }\end{array}$ & $\begin{array}{c}\text { Type of } \\
\text { lipoprotein }\end{array}$ & & Free & Esterified & $\begin{array}{c}\text { Cellular } \\
\text { protein } \\
\text { content }\end{array}$ \\
\hline & & & $\mu g$ sterol/mg protein & $\mu g /$ dish \\
$2 \%$ & Native LDL & & 21 & 2.5 & 176 \\
$2 \%$ & DMPA-LDL & & 72 & 166 & 197 \\
$10 \%$ & Native LDL & & 37 & 4.1 & 512 \\
$10 \%$ & DMPA-LDL & & 59 & 51 & 538 \\
\hline
\end{tabular}

On day $0,1 \times 10^{5}$ cells were seeded into each $60-\mathrm{mm}$ Petri dish in $3 \mathrm{ml}$ of medium containing 10\% FCS. Fresh medium with $10 \%$ FCS was added on days 2 and 5 . Beginning on day 7 , the culture medium contained the indicated concentration of FCS, and the cells were exposed to $10 \mu \mathrm{g}$ protein $/ \mathrm{ml}$ of either LDL or DMPA-LDL for 48-h periods (days 7 and 8,11 and 12,15 and 16 ) followed by 48 -h incubations in the absence of added lipoproteins (days 9 and 10,13 and 14, 17, and 18). On day 19, each monolayer was washed extensively (18), after which the cells were harvested for measurement of the cellular content of free and esterified cholesterol. Each value represents the average of duplicate incubations.

the cells had been subjected to prior incubation in LPDS, the cholesteryl ester content at the beginning of the experiment was less than $4 \mu \mathrm{g}$ sterol/mg cell protein (Fig. 1C, day 0 ). At the same time, the number of LDL receptors was high and hence the cells were able to bind a large amount of ${ }^{125}$ I-LDL (Fig. 1A) and degrade the lipoprotein at a rapid rate (Fig. 1B). In the presence of this large number of LDL receptors, the addition of native LDL produced a fourfold increase in the cellular content of cholesteryl esters on day 1 . Thereafter, however, the number of LDL receptors declined as indicated by the decreased ability of the cells to bind and degrade ${ }^{125} \mathrm{I}-\mathrm{LDL}$ after the 1st day. Because of this decrease, the cholesteryl ester content of the cells did not continue to rise after day 1 and actually declined significantly

$10 \mu \mathrm{g}$ protein $/ \mathrm{ml}$ of ${ }^{125} \mathrm{I}-\mathrm{LDL}(225 \mathrm{cpm} / \mathrm{ng})$. After incubation for $3 \mathrm{~h}$ at $37^{\circ} \mathrm{C}$, the amount of ${ }^{125} \mathrm{I}-\mathrm{LDL}$ bound to the cell surface and hence accessible for heparin release (A) and the amount of ${ }^{125} \mathrm{I}-\mathrm{LDL}$ degraded to TCA-soluble material (B) was determined. At zero time, more than $95 \%$ of the observed binding and degradation represented specific, high affinity processes as previously defined (25). For the second set of dishes (panel C), cell monolayers were washed, harvested, and pooled (three dishes per sample), and their content of esterified cholesterol was determined. Each value represents the average of duplicate incubations (A and $B$ ) or duplicate samples (C). 

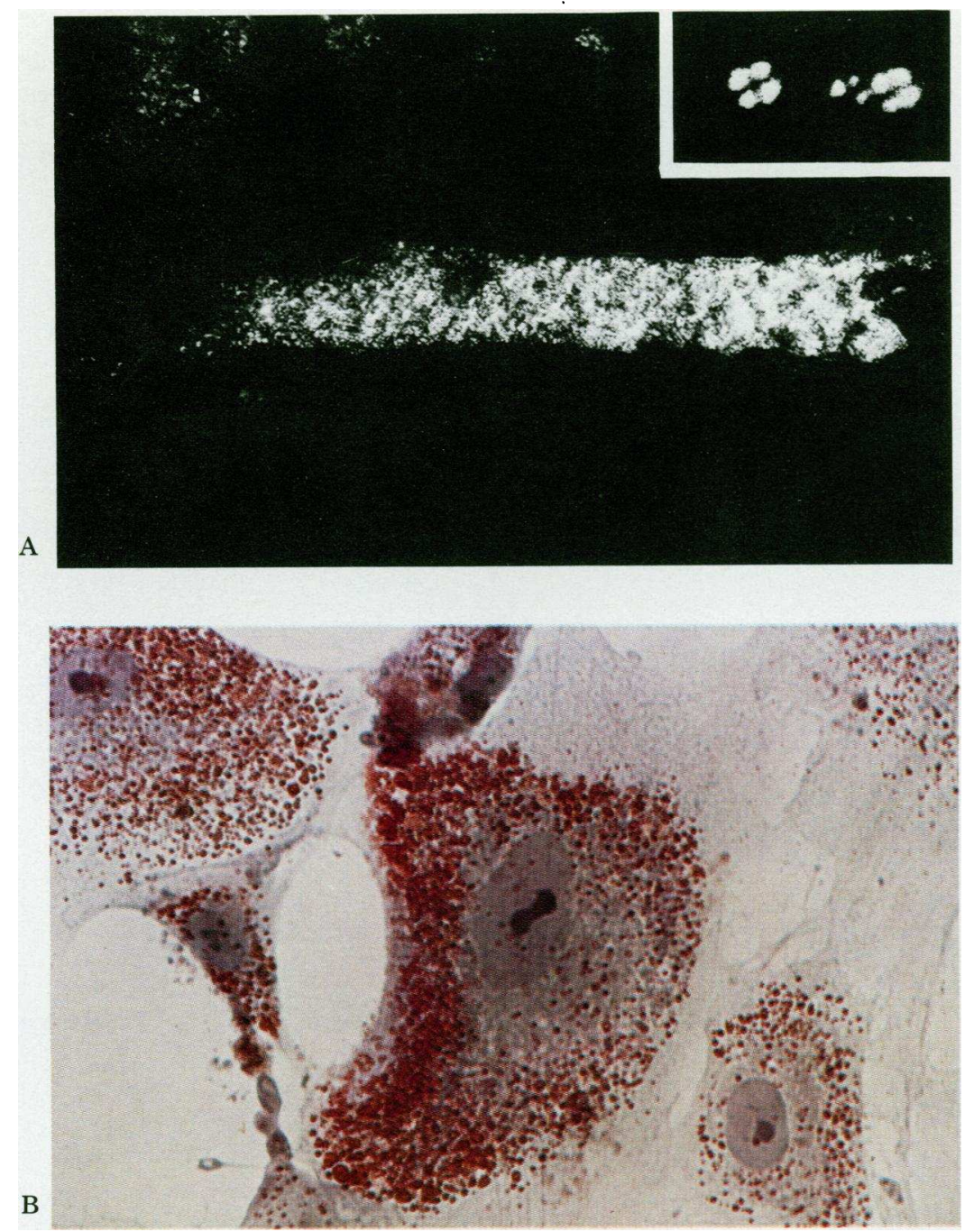

FIGURE 2 Light microscopic appearance of normal aortic smooth muscle cells that were repeatedly incubated with DMPA-LDL. Monolayers were grown on coverslips and incubated with $10 \mu \mathrm{g}$ protein/ml of DMPA-LDL in $2 \% \mathrm{FCS}$ as described in the legend to Table I. On day 19 , the coverslips were removed and either examined with polarizing microscopy (A) or stained with Oil Red 0 and hematoxylin (B). Magnifications: A, $\times 525$; A Inset, $\times 3,520 ; \mathrm{B}, \times 600$.

even though a constant level of native LDL was maintained in the culture medium. In other experiments, incubation of smooth muscle cells for 3 days with native LDL at concentrations as high as $300 \mu \mathrm{g}$ protein $/ \mathrm{ml}$ produced the same increase in the cellular content of cholesteryl esters as did $10 \mu \mathrm{g}$ protein/ $\mathrm{ml}$ (i.e., $7 \mu \mathrm{g}$ sterol/mg cell protein).

When DMPA-LDL was used in place of native LDL, the number of LDL receptors was similarly reduced (Fig. 1A). However, the uptake of the polycationic lipoprotein was not dependent upon the LDL receptor, and hence the cellular content of cholesteryl esters increased progressively over the 4-day period (Fig. 1C).
When smooth muscle cells were grown for periods of more than $1 \mathrm{wk}$ in the presence of DMPA-LDL, an even more massive increase in the content of cholesteryl esters was observed. This increase was similar whether the cells were exposed continuously to DMPA-LDL (data not shown) or whether they were subjected to several intermittent exposures of $48 \mathrm{~h}$ each (Table I). The cellular content of cholesteryl esters after intermittent exposure to DMPA-LDL was threefold higher when the cells were grown in $2 \% \mathrm{FCS}$ as compared to $10 \%$ FCS (Table I). When the cells were grown in $2 \%$ FCS, DMPA-LDL caused a 65 -fold higher level of cellular cholesteryl esters than did an equal concentration of native LDL. 

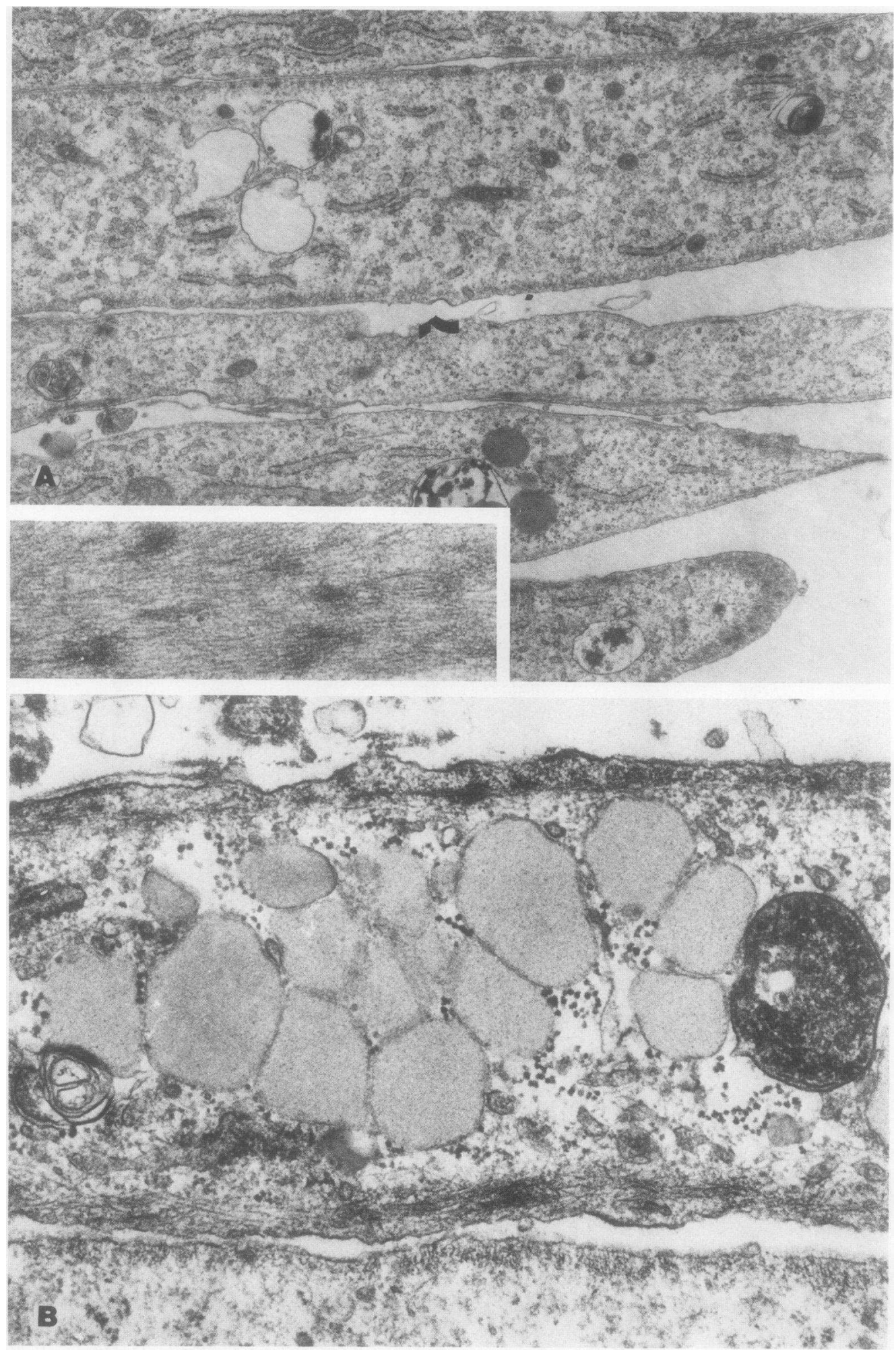

FIGURE 3 Electron microscopic appearance of normal aortic smooth muscle cells that were repeatedly incubated with either native LDL (A) or DMPA-LDL (B). Monolayers were incubated with $10 \mu \mathrm{g}$ protein/ml of either native LDL (A) or DMPA-LDL (B) in $2 \%$ FCS as described in the legend to Table I. On day 19, the cells were fixed in situ as described in Methods. Magnifications: A, $\times 14,600 ; \mathrm{B}, \times 42,200$. 
DMPA-LDL did not elevate the triglyceride content of the smooth muscle cells. In an experiment in which the cellular content of esterified cholesterol was 22fold higher in cells exposed to $10 \mu \mathrm{g}$ protein $/ \mathrm{ml}$ of DMPA-LDL as compared with an equal amount of native LDL ( 370 vs. $17 \mu \mathrm{g}$ sterol/mg protein), the content of cellular triglycerides was 82 and $72 \mu \mathrm{g} / \mathrm{mg}$ cell protein, respectively.

The massive accumulation of cholesteryl esters produced by DMPA-LDL could be visualized at the light and electron microscopic levels. In control cells incubated with native LDL, only occasional small lipid droplets were seen after staining with Oil Red 0 (data not shown). In contrast, cells incubated with the same concentration of DMPA-LDL showed large numbers of Oil Red 0 positive inclusions (Fig. 2B). The majority of these inclusions exhibited birefringence (Fig. 2A), and many showed typical formée crosses indicative of liquid crystals of cholesteryl esters $(4,22)$ (Fig. 2A, inset). The proportion of inclusions exhibiting formée crosses increased progressively for several days after DMPA-LDL was added to the culture medium, suggesting that the development of organized liquid crystals of cholesteryl ester may require a slow physical or chemical modification of the incoming DMPALDL by the cell.

The electron microscopic appearance of the cultured human aortic smooth muscle cells used in the current experiments was similar to that reported previously for human (23) and monkey aortic smooth muscle cells (24). In particular, the human smooth muscle cells showed abundant myofilaments (Fig. 3A, inset) and peripheral dense bodies (Fig. 3A). Ultrastructural examination of smooth muscle cells treated with DMPA-LDL showed that most of the cells had accumulated large numbers of homogeneous gray lipid droplets that were not surrounded by a typical tripartite limiting membrane (Fig. 3B). In contrast to this DMPALDL effect, smooth muscle cells treated with an equal amount of native LDL in the same experiments showed only an occasional neutral lipid droplet (Fig. 3A).

In the course of these experiments, we had the opportunity to study the metabolism of LDL in smooth muscle cells cultured from the thoracic aorta of a patient with homozygous FH. The binding, uptake, and degradation of ${ }^{125}$ I-LDL were markedly deficient in the mutant cells ( $<2 \%$ of normal values). As a result, these mutant smooth muscle cells did not exhibit normal LDL-mediated suppression of 3-hydroxy-3methylglutaryl CoA reductase activity or stimulation of cholesteryl ester formation. Despite their genetic lack of LDL receptors, the mutant smooth muscle cells accumulated cholesteryl esters to the same degree as did normal cells in the presence of DMPALDL (manuscript in preparation).

\section{DISCUSSION}

In the present studies, an unregulated uptake of LDL in aortic smooth muscle cells was achieved by enhancing the positive charge of the lipoprotein so that it entered the cells by a process not involving the physiologic LDL receptor. It is likely that within the athersoclerotic lesion a different mechanism is responsible for triggering the engorgement of smooth muscle cells with lipoprotein-bound cholesteryl esters. Nonetheless, it seems clear from the current data that when the LDL receptor regulatory system is bypassed and smooth muscle cells are forced to take up LDL in excess of their cholesterol requirements, they accumulate massive amounts of cholesteryl esters and develop morphologic abnormalities similar to those of the smooth muscle cells of the atherosclerotic lesion in vivo (1-5). These studies thus emphasize the critical role of the regulation of the LDL receptor in protecting aortic smooth muscle cells against an overaccumulation of cholesteryl esters when they are exposed to large amounts of native LDL.

\section{ACKNOWLEDGMENTS}

Gloria Y. Brunschede, Jerry R. Faust, and Margaret Wintersole provided excellent technical assistance.

This research was supported by grants from the National Institutes of Health (GM 19258, HL 16024, and GM 21698).

\section{REFERENCES}

1. Lang, P. D., and W. Insull, Jr. 1970. Lipid droplets in atherosclerotic fatty streaks of human aorta. J. Clin Invest. 49: 1479-1488.

2. Smith, E. B., and R. H. Smith. 1976. Early changes in aortic intima. In Atherosclerosis Reviews. R. Paoletti and A. M. Gotto, Jr., editors. Raven Press, New York. 1: 119-136.

3. Geer, J. C., and M. D. Haust. 1972. Smooth muscle cells in atherosclerosis. Monogr. Atheroscler. 2: 1-137.

4. Hata, Y., J. Hower, and W. Insull, Jr. 1974. Cholesteryl ester-rich inclusions from human aortic fatty streak and fibrous plaque lesions of atherosclerosis. I. Crystalline properties, size and internal structure. Am. J. Pathol. 75: 423-456.

5. McGill, H. C., Jr., and J. C. Geer. 1963. The human lesion, fine structure. In Evolution of the Atherosclerotic Plaque. R. J. Jones, editor. The University of Chicago Press, Chicago. 65-76.

6. Smith, E. B. 1974. The relationship between plasma and tissue lipids in human atherosclerosis. Adv. Lipid Res. 12: 1-49.

7. Pearson, J. D. 1976. Lipid metabolism in cultured aortic smooth muscle cells and comparison with other cell types. Part I. Composition of cells grown in hyperlipemic serum. Atherosclerosis. 24: 233-242.

8. Nikkari, T., K. Pietila, and M. Salo. 1976. Increased cholesterol content and esterification in rabbit aortic medial cells cultured in hyperlipidemic serum. Med. Biol. (Helsinki). 54: 264-271.

9. Mahley, R. W., T. L. Innerarity, K. H. Weisgraber, and D. L. Fry. 1977. Canine hyperlipoproteinemia and

Cholesteryl Ester Overaccumulation

1201 
atherosclerosis: Accumulation of lipid by aortic medial cells in vivo and in vitro. Am. J. Pathol. In press.

10. Brown, M. S., and J. L. Goldstein. 1976. Receptor-mediated control of cholesterol metabolism. Study of human mutants has disclosed how cells regulate a substance that is both vital and lethal. Science (Wash. D. C.). 191: $150-154$.

11. Goldstein, J. L., and M. S. Brown. 1976. The LDL pathway in human fibroblasts: A receptor-mediated mechanism for the regulation of cholesterol metabolism. Curr. Top. Cell Regul. 11: 147-181.

12. Goldstein, J. L., and M. S. Brown. 1977. The low density lipoprotein pathway and its relation to atherosclerosis. Annu. Rev. Biochem. 46: 897-930.

13. Basu, S. K., J. L. Goldstein, R. G. W. Anderson, and M. S. Brown. 1976. Degradation of cationized low density lipoprotein and regulation of cholesterol metabolism in homozygous familial hypercholesterolemia fibroblasts. Proc. Natl. Acad. Sci. U. S. A. 73: 3178-3182.

14. Bilheimer, D. W., J. L. Goldstein, S. M. Grundy, and M. S. Brown. 1975. Reduction in cholesterol and low density lipoprotein synthesis after portacaval shunt surgery in a patient with homozygous familial hypercholesterolemia. J. Clin. Invest. 56: 1420-1430.

15. Ross, R. 1971. The smooth muscle cell. II. Growth of smooth muscle in culture and formation of elastic fibers. J. Cell Biol. 50: 172-186.

16. Brown, M. S., S. E. Dana, and J. L. Goldstein. 1974. Regulation of 3-hydroxy-3-methylglutaryl coenzyme A reductase activity in cultured human fibroblasts. Comparison of cells from a normal subject and from a patient with homozygous familial hypercholesterolemia. J. Biol. Chem. 249: 789-796.

17. Brown, M. S., and J. L. Goldstein. 1974. Familial hypercholesterolemia: Defective binding of lipoproteins to cultured fibroblasts associated with impaired regulation of 3-hydroxy-3-methylglutaryl coenzyme A reductase activity. Proc. Natl. Acad. Sci. U. S. A. 71: 788-792.

18. Goldstein, J. L., S. K. Basu, G. Y. Brunschede, and M. S. Brown. 1976. Release of low density lipoprotein from its cell surface receptor by sulfated glycosaminoglycans. Cell. 7: 85-95.

19. Goldstein, J. L., and M. S. Brown. 1974. Binding and degradation of low density lipoproteins by cultured human fibroblasts. Comparison of cells from a normal subject and from a patient with homozygous familial hypercholesterolemia. J. Biol. Chem. 249: 5153-5162.

20. Brown, M. S., J. R. Faust, and J. L. Goldstein. 1975. Role of the low density lipoprotein receptor in regulating the content of free and esterified cholesterol in human fibroblasts. J. Clin. Invest. 55: 783-793.

21. Lowry, O. H., N. J. Rosebrough, A. L. Farr, and R. J. Randall. 1951. Protein measurement with the Folin phenol reagent. J. Biol. Chem. 193: 265-275.

22. Katz, S. S., G. G. Shipley, and D. M. Small. 1976. Physical chemistry of the lipids of human atherosclerotic lesions. Demonstration of a lesion intermediate between fatty streaks and advanced plaques. J. Clin. Invest. 58: $200-211$.

23. Layman, D. L., and J. L. Titus. 1975. Synthesis of Type I collagen by human smooth muscle cells in vitro. Lab. Invest. 33: 103-107.

24. Ross, R., and J. A. Glomset. 1973. Atherosclerosis and the arterial smooth muscle cell. Proliferation of smooth muscle is a key event in the genesis of the lesions of atherosclerosis. Science (Wash. D. C.). 180: 1332-1339.

25. Goldstein, J. L., M. K. Sobhani, J. R. Faust, and M. S. Brown. 1976. Heterozygous familial hypercholesterolemia: Failure of normal allele to compensate for mutant allele at a regulated genetic locus. Cell. 9: 195-203. 